\title{
Investigation of the Presence of Sildenafil in Herbal Dietary Supplements by Validated HPLC Method
}

\author{
Bitkisel Diyet Takviyelerinde Sildenafil Varlığının Valide Bir HPLC \\ Yöntemiyle Araştırılması
}

\author{
(1) Emrah DURAL* \\ Sivas Cumhuriyet University, Faculty of Pharmacy, Department of Pharmaceutical Toxicology, Sivas, Turkey
}

\begin{abstract}
Objectives: As the first FDA-approved phosphodiesterase type 5 inhibitor, sildenafil (SDF) is widely used in the treatment of erectile dysfunction due to its strong pharmacodynamic activity. Since many food supplements are now involved in illegal adulteration, the presence of SDF in food supplements is very important because of their toxicological risks. In this study a simple fast, reliable high-performance liquid chromatography method with ultraviolet (UV) detector has been developed and validated for SDF analysis in herbal dietary supplements (HDSs).

Materials and Methods: $10 \mathrm{mM}$ phosphate buffer containing $0.1 \%$ triethylamine $(\mathrm{pH} 3.5)$ and acetonitrile (65:35, v/v), as mobile phase was applied isocratically to a reverse phase $\mathrm{C} 18$ analytical $(4.6 \times 250 \mathrm{~mm}, 5 \mu \mathrm{m})$ column. Chromatographic separation was achieved by a $\mathrm{C}_{18}$ reverse-phase analytical column $4.6 \times 250 \mathrm{~mm}, 5 \mu \mathrm{m}$ particle size, using acetonitrile, with $10 \mathrm{mM}$ phosphate buffer containing $0.1 \%$ triethylamine $(65: 35$, v/v, pH 3.5) as a mobile phase. The mobile phase flow rate was $1 \mathrm{~mL} \mathrm{~min}-1$ and the column temperature was $35^{\circ} \mathrm{C}$. The UV detector was set at $293 \mathrm{~nm}$. The liquid-liquid extraction method used in the study provided a simple and practical method for the recovery of SDF in HDSs and their obtained values ranged from 87.6 to $111.7 \%$.

Results: The method showed linearity with an excellent correlation coefficient $\left(r^{2}>0.999\right)$. Moreover, it was specific and sensitive with the limit of quantification, $6.5 \mathrm{ng} \mathrm{mL}^{-1}$. Intraday and interday method precision was $\leq 8.2$ (relative standard deviation \%). Intraday and interday method accuracy was between -4.0 and 7.1 (RE\%). The method was strong according to the robustness test results obtained from UV detection, mobile phase buffer $\mathrm{pH}$, column temperature, and flow rate changes. The described procedure was simple, fast, precise, and feasible for routine adulteration analysis of SDF, especially in food control or toxicology laboratories. This method was successfully applied to 50 individual solid and liquid form HDSs.

Conclusion: The results showed that 37 out of 50 samples of HDSs (represented 74.0\%) examined contained SDF between 0.01 and $465.47 \mathrm{mg} / \mathrm{g}$, $150.87 \pm 127.48$ (mean \pm standard deviation), which could lead to serious health problems and might even be fatal for consumers. The described procedure was found to be simple, rapid, precise and feasible for routine adulteration analysis of SDF, especially in food control or toxicology laboratories.
\end{abstract}

Key words: Sildenafil, adulteration, herbal dietary supplements, validation, high-performance liquid chromatographic-ultraviolet detection

ÖZ

Amaç: FDA tarafından onaylı ilk fosfodiesteraz-5 inhibitörü olan sildenafil (SDF), güçlü farmakodinamik etkinliği sebebiyle erektil fonksiyon bozukluğunun tedavisinde yaygın olarak kullanılmaktadır. Günümüzde birçok gıda takviyesi, yasadışı tağșiș ișlemlerine dahil olduğundan, gıda takviyelerinin içerisindeki SDF varlığının belirlenmesi toksikolojik riskleri sebebiyle çok önemlidir. Bu çalışmada bitkisel gıda takviyelerinde (BGT) SDF analizi için basit, hızlı, güvenilir bir ultraviyole (UV) detektörlü yüksek performanslı sıvı kromatografi yöntemi geliștirilmiş ve valide edilmiştir. Gereç ve Yöntemler: Mobil faz olarak içeriğinde \%0,1 trietilamin bulunan 10 mM'lik fosfat tamponu (pH 3,5) ve asetonitril (65:35, v/v) bir ters faz C18 analitik kolonuna $(4,6 \times 250 \mathrm{~mm}, 5 \mu \mathrm{m})$ izokratik olarak uygulanmıştır. Mobil faz akış hızı $1 \mathrm{~mL} \mathrm{dk}^{-1}$ ve kolon sıcaklığı $35^{\circ} \mathrm{C}$ idi. UV dedektör 293 nm'ye ayarlanmıştır. Çalışmada kullanılan sıvı-sıvı ekstraksiyon yöntemi, BGT'lerde SDF'nin geri kazanımı için basit ve pratik bir yöntem sağladı ve elde edilen değerleri \%87,6 ila 111,7 arasındaydı.

Bulgular: Yöntem, mükemmel bir korelasyon katsayısı ile doğrusallık göstermiștir $\left(r^{2}>0,999\right)$. Ayrıca, metot $6,5 \mathrm{ng} \mathrm{mL}^{-{ }^{\prime \prime}}$ lik tayin limitiyle seçici ve hassastı. Gün içi ve günler arası metot kesinlik s\%8,2 (\% bağıl standart sapma) idi. Gün içi ve günler arası metot doğruluk testi sonuçları (-4,0) ile

*Correspondence: E-mail: emrahdural@cumhuriyet.edu.tr, Phone: +90 3462191010 (\#39 20) ORCID-ID: orcid.org/0000-0002-9320-8008

Received: 24.07.2018, Accepted: 25.10.2018

-Turk J Pharm Sci, Published by Galenos Publishing House. 
7,1 (\%RE) arasındaydı. Metodun UV tespiti, mobil faz tampon pH'sı, kolon sıcaklığı ve akış hızı değişimlerinden elde edilen sonuçlarla sağlam olduğu görüldü. Bu yöntem birbirinden ayrı katı ve sıvı formdaki 50 adet BGT'ye başarıyla uygulanmıștır.

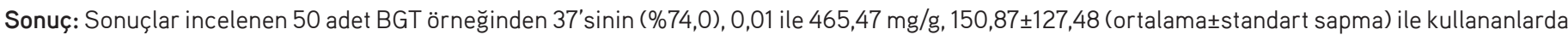
ciddi sağlık sorunlarına yol açabilecek hatta ölümcül bile olabilecek kadar SDF içerdiğini gösterdi. Tanımlanan prosedürün, özellikle gıda kontrol veya toksikoloji laboratuvarlarında SDF'nin rutin tağșiş analizleri için basit, hızlı, kesin ve uygulanabilir olduğu görülmüștür.

Anahtar kelimeler: Sildenafil, tağșiș, bitkisel gıda takviyeleri, validasyon, yüksek-performanslı sıvı kromatografisi-ultraviyole dedeksiyon

\section{INTRODUCTION}

Sildenafil (SDF), 1-[(3-(6.7-dihydro-1-methyl-7-oxo-3-propyl$1 \mathrm{H}$-pyrazolo(4.3-d)pyrimidin-5-yl)-4-ethoxyphenyl) sulfonyl)4-methyl piperazine citrate] (Figure 1a) is a potent and selective inhibitor of the cyclic guanosine monophosphate (cGMP)specific phosphodiesterase type 5 (PDE-5) mainly found in the penile corpus cavernosum that causes cGMP to accumulate in the corpus cavernosum. ${ }^{1.2}$ cGMP, which is broken down by PDE-5, is directly responsible for producing smooth muscle relaxation in the corpus cavernosum and allowing the inflow of blood. ${ }^{3}$

SDF, the first synthetic PDE-5 inhibitor licensed for clinical use, has the ability to enhance relaxation of the corpus cavernosum and therefore can potentially improve penile erectile function. ${ }^{4,5}$ Since SDF is considered an effective oral agent for the treatment of male erectile dysfunction, it has been extensively used to improve erectile dysfunction. In addition, SDF has been also used commonly in the treatment of pulmonary hypertension disease successfully. ${ }^{6}$

The structural formula is $\mathrm{C}_{22} \mathrm{H}_{30} \mathrm{~N}_{6} \mathrm{O}_{4} \mathrm{~S}$. SDF is an ampholyte with pKa value 4 (pyridinium ion) and 8.8 (benzmidazole). SDF is soluble in both methanol and water. ${ }^{7} \mathrm{SDF}$ is rapidly absorbed with approximately $40 \%$ bioavailability by the gastrointestinal tract and rapidly and widely metabolized to active $\mathrm{N}$-desmethyl sildenafil (N-SDF) as a major metabolite by the CYP3A4 and CYP2C9 hepatic microsomal enzymes after oral administration. The elimination half-life of both SDF and $\mathrm{N}$-SDF is approximately 2.5 h. ${ }^{8,9}$

SDF is a relatively safe drug with an upper limit of $100 \mu \mathrm{g} /$ day. However, it has some serious side effects that may create potential hazards. It has been reported to seriously potentiate the hypotensive effects of nitrates commonly employed in

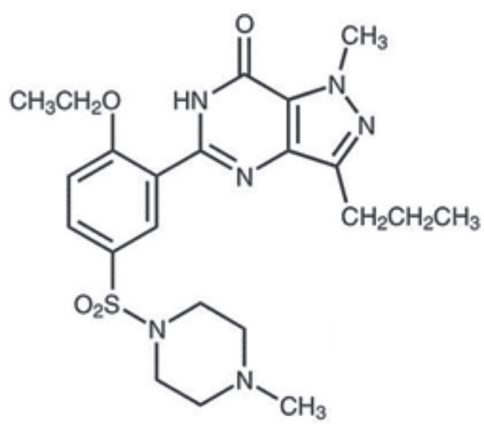

A

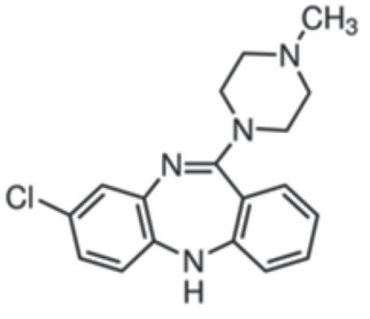

B
Figure 1. Chemical structure of SDF (A) and CZP (B) used as an internal standard

SDF: Sildenafil, CZP: Clozapine the treatment of certain heart impairments. This side effect, which occurs in combination with nitrates and can cause risk of death, is very important toxicologically. Clinical studies have also reported blindness in one eye as an adverse effect of administration of SDF. SDF also has a high affinity for phosphodiesterase type 6 (PDE-6), which is a retinal enzyme involved in phototransduction. The inhibition of PDE-6 can result in a situation known as blue tinge, which prevents the ability to distinguish between blue and green colors. Although only $3 \%$ of patients report visual disturbances, this blue-green impairment can cause problems when fulfilling certain tasks. For example, this degradation can lead to problems for pilots during night flights or adverse meteorological conditions..$^{10}$

Because people consider that natural substances are safer and healthier than synthetic derivatives, herbal dietary supplements (HDSs) have widely increased as alternatives to chemically synthetic products recently." The adulteration with SDF in varying doses of herbal products sold for the treatment of erectile dysfunction is a serious potential health hazard. Although drugs containing SDF need to be prescribed under medical supervision, they are used without prescription in many countries, including Turkey. The sale of these medicines without medical advice causes patients to use them in high doses to gain more effect. It is known that the adulteration of HDSs with SDF is illegal and when a patient who is undergoing medical treatment with SDF also uses HDSs adulterated with SDF serious results may emerge. However, the presence of HDSs containing SDF marketed without controls in Turkey and around the world is frequently reported.

Therefore, consumption of HDSs that might be adulterated with SDF can produce serious toxic effects. For the purposes of quality control and product safety, analytical procedures need to be established that can selectively detect and quantify SDF in dosages in adulterated herbal products.

Several techniques are reported for the determination of SDF in many kinds of food supplements and pharmaceutical formulations, namely flow injection analysis, ${ }^{2}$ thin layer chromatography (TLC),12 spectrophotometry, ${ }^{2,13}$ spectrofluorometry, ${ }^{14}$ high-performance liquid chromatography (HPLC)-ultraviolet (UV), ${ }^{7,5-17}$ HPLC-diode array detection, 12,18 HPLC-electrospray ionization-mass spectrometry (ESIMS) ${ }^{19}$ micellar electrokinetic chromatography, ${ }^{4}$ electrospray tandem (ESI)-MS," gas chromatography (GC)-MS, ${ }^{20,21}$ liquid chromatography (LC)-MS, ${ }^{12}$ and LC-MS. ${ }^{22,23}$

In addition, low analytical sensitivity, inadequate intraday and interday reproducibility values, and inappropriate recovery amounts cause problems with the use of these techniques. 
Spectrophotometer analyses can lead to false positive results due to chemical interactions with molecules with similar chemical properties through the absence of pre-separation through a column. TLC assays do not show sufficient analytical sensitivity in routine assays with the long analysis times and difficulties of quantification. Analysis of SDF by GC-MS does not show sufficient analytical sensitivity due to its chemical properties, that is its low transition to the gas phase. Although the LC-MS is a device with high analytical sensitivity, it is less common in toxicological analysis laboratories due to its high cost. Moreover, its per analysis cost is higher than that of other techniques. HPLC-UV-based analytical techniques provide sufficient analytical sensitivity and reproducibility to determine the amount of SDF in food supplements, biological fluids, and other many matrices.

Our study of the analysis of SDF content in HDSs with HPLC-UV provides a significant advantage with high analytical accuracy and precision, low cost per analysis, and fast retrieval of results. This method was based on separation with an analytical column $4.6 \times 250 \mathrm{~mm}, 5 \mu \mathrm{m}$ particle size, using acetonitrile, and $10 \mathrm{mM}$ phosphate buffer ( $\mathrm{pH} 3.5$ ) containing $0.1 \%$ triethylamine (65:35, $\mathrm{v} / \mathrm{v}$ ) as the mobile solvent. The UV detector was set at $293 \mathrm{~nm}$ and the total analysis time was $7.5 \mathrm{~min}$. Clozapine (CZP) was used as an internal standard (ISTD). The developed method was also validated with linearity, accuracy, precision, sensitivity, recovery, and robustness according to the $\mathrm{ICH}-2005$ guideline. The validity of the developed method has been proved by analyzing 50 HDSs that were liquid (liquid and paste) and solid (tablet, capsule, and powder) form. The results showed that products sold as HDSs for the treatment of erectile dysfunction seriously threatened public health, since SDF content was found to be in the range of 0.01 to $465.47 \mathrm{mg} / \mathrm{g}$ in 37 of the 50 samples (74\%) analyzed in terms of SDF contents $(150.87 \pm 127.48, \bar{x} \pm$ Standard deviation).

\section{MATERIALS AND METHODS}

\section{Chemicals and reagents}

Pure reference samples of SDF (Figure 1a) and CZP as the ISTD (Figure 1b) were purchased from Sigma-Aldrich (Steinheim, Germany). HPLC grade methanol and acetonitrile were obtained from Sigma-Aldrich (St. Louis, MO, USA). Analytical grade triethyl amine, orthophosphoric acid, potassium dihydrogen phosphate, sodium carbonate, and sodium sulfate were purchased from Merck (Darmstadt, Germany). Ultrapure water was made by Elga Purelab (High Wycombe, United Kingdom) system. A polytetrafluoroethylene disc filter $(0.45 \mu \mathrm{m})$ was used to purify the HDSs. Membrane filters with a pore size of $0.45 \mu \mathrm{m}$ from Millipore (Burlington, MA, USA) were used for filtration of the mobile phase.

\section{Instrumentation}

The separation and quantification were performed by HP Agilent 1100 series (Palo Alto, CA, USA) HPLC system, equipped with a UV detector. A HPLC system was employed in the present study; it consisted of a gradient pump (G1311A), a degasser (G1312), a column oven (G1316A), a UV detector (G1314A), and a Rheodyne 7725i manual injector with a $20-\mu \mathrm{L}$ sample loop. ChemStation $^{\circledR}$ version 08.03 software was employed for data collection and handling.

\section{Chromatographic conditions}

Separations were carried out on an ACE-5 (Aberdeen, Scotland) reverse phase $C_{18}$ analytical column $(4.6 \times 250 \mathrm{~mm}, 5 \mu \mathrm{m}$ particle size). The analysis was carried out under isocratic conditions using a flow rate of $1.0 \mathrm{~mL} \mathrm{~min}^{-1}$ at $35^{\circ} \mathrm{C}$. Chromatographic quantitation was conducted at $293 \mathrm{~nm}$. The mobile phase consisted $10 \mathrm{mM}$ phosphate buffer (containing $0.1 \%$ triethyl amine) and acetonitrile $(65: 35, \mathrm{v} / \mathrm{v})$ before delivery into the HPLC system. The mobile phase $\mathrm{pH}$ was adjusted to 3.5 with 1 $\mathrm{M}$ phosphoric acid. It was degassed before every use over 30 min using an ultrasonic bath.

\section{Collection of samples and its preparation to analysis}

Fifty-one different HDSs advertised to enhance sexual performance in men from individual brands were purchased online and from an herbal market in Sivas. All the solid drug and tablet samples were pulverized by a mortar. An exactly weighed $200 \mathrm{mg}$ (liquid, solid, and powdered) sample was dissolved in a $10 \mathrm{~mL}$ mixture of methanol and $1.5 \% \mathrm{Na}_{2} \mathrm{CO}_{3}(7: 3, \mathrm{v} / \mathrm{v})$. After that, the mixture was dried with $250 \mathrm{mg}$ of $\mathrm{Na}_{2} \mathrm{SO}_{4}$. The extract was mixed over $10 \mathrm{~min}$ at $1200 \mathrm{rpm}$ in a rotator shaker and dissolved in an ultrasonic bath over $30 \mathrm{~min}$. The sample was centrifuged at $3000 \mathrm{rpm}$ for $5 \mathrm{~min}$ and approximately $10 \mathrm{~mL}$ of the upper phase was transferred to a clean test tube and filtered by a $0.45-\mu \mathrm{m}$ disc filter. Then $10 \mu \mathrm{L}$ of sample filtrate and $10 \mu \mathrm{L}$ of ISTD $\left(100 \mu \mathrm{g} \mathrm{mL}^{-1}\right)$ were completed to $10 \mathrm{~mL}$ with the mobile phase and vortexed at $1200 \mathrm{rpm}$ for $1 \mathrm{~min}$. Finally, $20 \mu \mathrm{L}$ of this mixture was applied to the liquid chromatograph under specified chromatographic conditions.

\section{Preparation of standard solutions}

A SDF stock solution (1 $\mathrm{mg} \mathrm{mL}^{-1}$ ) was prepared in methanol and stored at $-20^{\circ} \mathrm{C}$. It has been quantitatively determined that it is chemically stable for at least 3 months. Working solutions were prepared by main stock solution weekly in methanol at 10, 20 , $30,40,60,80$, and $100 \mu \mathrm{g} \mathrm{mL}^{-1}$ concentrations. The ISTD main stock solution (10 $\mathrm{mg} \mathrm{mL}^{-1}$ ) was prepared with methanol to yield a $100 \mu \mathrm{g} \mathrm{mL} \mathrm{m}^{-1}$ working solution.

\section{RESULTS AND DISCUSSION}

\section{Method validation}

The method developed was validated in terms of specificity, linearity, accuracy, precision, sensitivity, recovery, and robustness. In order to obtain accurate and precise measurements in accordance with the International Harmonization Conference, the intraday and interday validity protocols were implemented taking into account the reproducibility of the method and instrument. $^{24}$

\section{Specificity}

Specificity is the ability of the method to measure the analyte response in the presence of all the impurities that may arise from the analyte and other conditions. The UV detector was 
set to a wavelength of $293 \mathrm{~nm}$ displaying optimum sensitivity. Figures 2a, 2b, and 2c show chromatograms of blank, spiked, and real samples illustrating the high resolution with no interference and too short separation time $(7.5 \mathrm{~min})$. The method demonstrated excellent chromatographic specificity with no endogenous interference at the retention times of SDF and CZP (6.2 and $6.7 \mathrm{~min}$, respectively) as an ISTD.

\section{Linearity and selectivity}

After establishing the chromatographic conditions, the linearity of SDF was studied by preparing standard solutions at 7 different levels ranging from 10 to $1000 \mathrm{ng} \mathrm{mL}^{-1}$. Calibration was performed by linear regression of peak-area ratios of SDF to the ISTD versus the respective standard concentration. For each concentration 3 individual replicates were injected and linearity was obtained for SDF with high correlation coefficients $\left(r^{2}\right)$ over 0.999 (Table 1). System suitability parameters are tabulated in Table 2.

\section{Precision and accuracy}

The precision and accuracy of the method were examined on 5 consecutive days. Precision, defined as relative standard deviation (RSD), was determined by five individual replicates at three different concentrations, which were 20, 100, and 500 $n g \mathrm{~mL}^{-1}(\mathrm{n}=5)$. Table 3 shows the RSD values of low, medium, and high concentrations (20,100, and $500 \mathrm{ng} \mathrm{mL}^{-1}$, respectively) to present inter- and intraday precision. Accuracy, defined as relative error (RE\%), was also determined for the same concentrations of analytes (Table 3 ).

\section{Recovery}

The recovery of the method was calculated by comparing the results obtained from the application of the standard sample prepared in methanol to the samples prepared in the same concentration in the herbal sample. The recovery results conducted at 20,100 , and $500 \mathrm{ng} \mathrm{mL}^{-1}$ are tabulated in Table 3.

\section{Sensitivity}

The limit of detection (LOD) and limit of quantification (LOQ) were determined based on the standard deviation of the

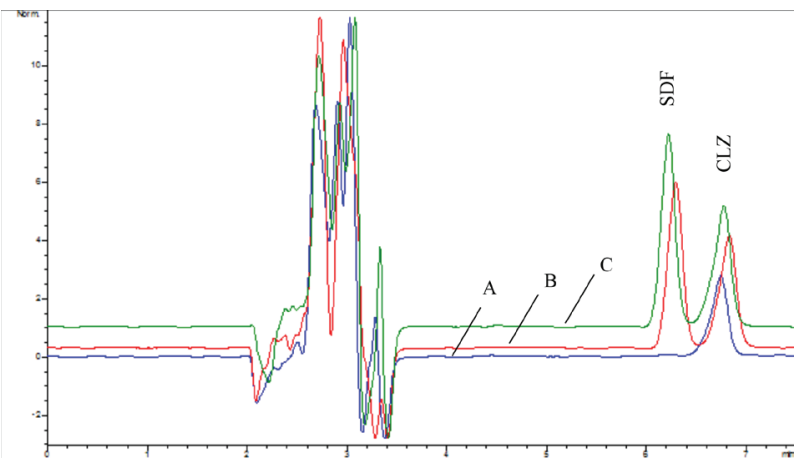

Figure 2. A. The chromatogram of the SDF blank sample that belongs to HDS extract used as a quality control sample in validation tests. B. The chromatogram of an HDS extract that was prepared by standard addition method containing $1000 \mathrm{ng} \mathrm{mL-1} \mathrm{SDF.} \mathrm{C.} \mathrm{The} \mathrm{chromatogram} \mathrm{of} \mathrm{a} \mathrm{real} \mathrm{HDS}$ sample extract determined to be adulterated with SDF.

SDF: Sildenafil, HDS: Herbal dietary supplements, CLZ: Clozapine response and the slope of the calibration curve, according to the International Council for Harmonisation of Technical Requirements for Pharmaceuticals for Human Use $(\mathrm{ICH})$ guidelines. ${ }^{24}$ ( $L O D=3.3 \sigma / S, L O Q=10 \sigma / S$, where $\sigma$ is the standard deviation of the response and $S$ is the slope of the calibration curve). The $L O D$ and $L O Q$ values of the method were $1.94 \mathrm{ng}$ $\mathrm{mL}^{-1}$ and $6.46 \mathrm{ng} \mathrm{mL}^{-1}$, respectively.

\section{Robustness}

Significant changes were not observed in the analytical signals upon changing the UV wavelength value $( \pm 2 \mathrm{~nm})(p>0.05)$, mobile phase buffer $\mathrm{pH}( \pm 0.3)(\mathrm{p}>0.05)$, column temperature $\left( \pm 4^{\circ} \mathrm{C}\right)(p>0.05)$, or mobile phase flow rate $\left( \pm 0.1 \mathrm{~mL} \mathrm{~min}^{-1}\right)$ ( $p>0.05)$. The statistics were evaluated by SPSS 15 - KruskalWallis test. In addition, changes in analyst, analytical column, the source of chemical, and/or solvent did not lead to significant changes in chromatographic signals. Robustness experiments demonstrated that the method created data of acceptable precision and accuracy. After the data from the validation tests were found to be appropriate for safe analysis, the survey of the SDF in real HDSs was initiated.

\section{Analysis of samples}

A quantitative investigation of SDF contents in 50 HDSs used for the treatment of erectile dysfunction sold in an herbal market and on the Internet was conducted. Solid and liquid supplement samples were prepared according to the sample preparation

Table 1. The analytical parameters of the proposed HPLC method

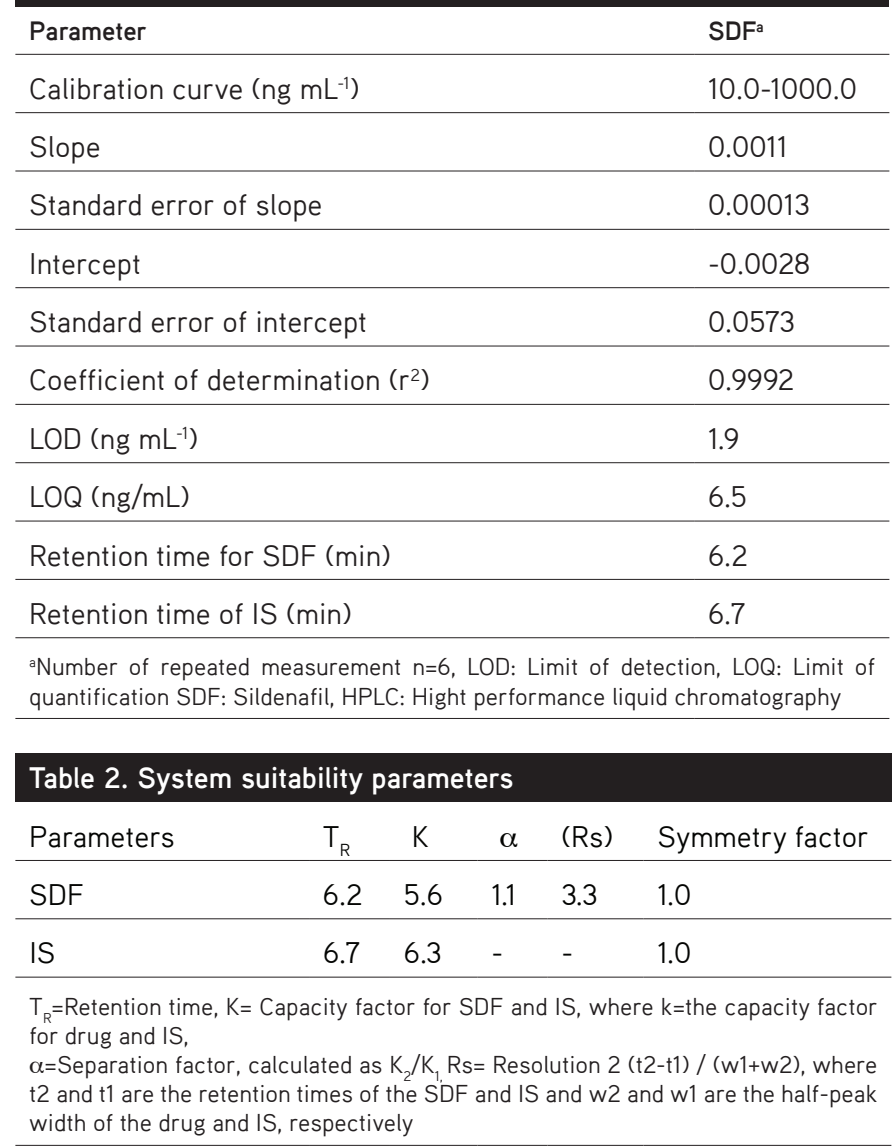


procedure explained above. The measurement results are given in Table 4. Sample chromatograms are shown in Figure 3.

\section{CONCLUSION}

In our study, the presence of SDF was quantitatively investigated in 50 products described as ginseng, panax, epimedium, herbal mixtures, and herbal supplements on product packages by the developed and also validated method in accordance with $\mathrm{ICH}$ (2005) Guidelines. ${ }^{24}$ The SDF positive samples known as HDSs were in the form of pills, capsules, powders, syrups, liquids, and pastes. These food supplements that were positive for SDF analysis were all different shades of green and brown. Some of the products analyzed gave the impression that they were malodorous herbal medicines. In addition, some analyzed herbal products were enriched with chocolate, lemon juice, and other sweeteners. In addition, there was a malodorous product that was difficult for a person to swallow in one go because of its size, $3 \mathrm{~cm}$ in diameter. Powdered products were usually brown and gray in color and had a sharp spice smell. Liquid products were light green. It is thought that these processes are intended to convince users that the products are natural.

It has been reported that SDF is a safe drug for therapeutic use. However, the use of SDF-containing medical tablets as well as a user who considers taking a natural product will cause an overdose. The tendency to use more of the recommended product for the expected increase in activity, as well as the product thought to be natural, is often common in individuals who use food supplements. It is also known that the use of SDF

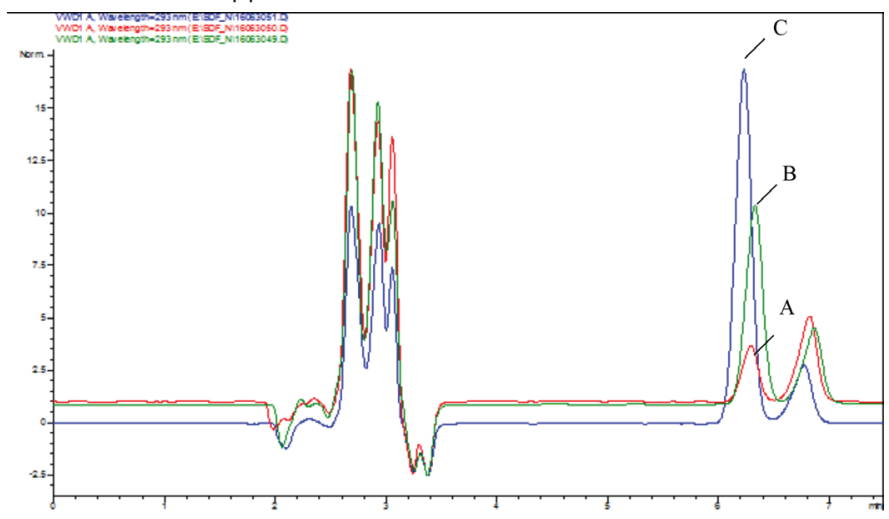

Figure 3. Real HDS sample chromatograms containing SDF ( $A=$ sample 50, $\mathrm{B}=$ sample 49 , and $\mathrm{C}=$ sample 51)

HDS: Herbal dietary supplements, SDF: Sildenafil in combination with organic nitrates significantly increases systemic blood pressure lowering effects. An overdose can create a serious risk for the cardiovascular system. It is known that individuals who frequently use these products are men over 50 years old and cardiovascular system diseases increase in this group during this period.

However, SDF has been found in quantities of 0.01 to 465.47 $\mathrm{mg} / \mathrm{g}(150.87 \pm 127.48$, mean \pm standard deviation $)$ in 37 products with positive results, which could harm human health even after a single use (Table 4). It has been reported that these products have been sold at a higher rate than others with low SDF content. It has also appeared on product packages that the same products are more effective in the treatment of erectile dysfunction. It has been determined that some of the herbal products studied contain SDF in almost half of their weight.

This study was carried out due to the fact that there is no method in the literature that is analyzed with a simple, uncomplicated analytical device with low cost of analysis. In our study, a new HPLC-based analysis method was developed for the determination of illegal addition of SDF to herbal products and the method was validated and the applicability of the method was shown with 50 samples. The method developed has significant advantages, such as rapid analysis with a total analysis time of $7.5 \mathrm{~min}$, a low sample requirement $(0.2 \mathrm{~g})$, and high analytical accuracy (LOD: $1.88 \mathrm{ng} \mathrm{mL}^{-1}$ ). The method developed is noteworthy due to its intraday and interday reproducibility values, which were between 2.34 and 8.13 (RSD\%) for precision and between -4.02 and 7.14 (RE\%) for accuracy, and recovery values were between $87.57 \%$ and $111.65 \%$. The method was also proven to be robust against changes in some analytical conditions such as mobile phase content, column temperature, and flow rate, as well as robustness tests. The method was also easily applied to 50 herbal products and the analyses were successfully completed in all products. In addition, during sample preparation and analysis only a small amount of solvent was used. Our study methodology was compared with the other HPLC study results in Table 5.

A total of 50 products marketed as herbal products for the treatment of erectile dysfunction were exposed to serious abuse. Measures to prevent international marketing of these products, which seriously threaten public health, are needed. Although the products examined are visually similar to a medicinal product, they are marketed as "herbal products" online and in markets selling herbal products. These synthetic

Table 3. Confidence parameters of the validated method; intraday and interday precision and accuracy and recovery parameters of validated method; at 20, 100, and $500 \mathrm{ng} \mathrm{mL}^{-1}$ concentration for determination of SDF

\begin{tabular}{|c|c|c|c|c|c|c|c|c|}
\hline \multirow{2}{*}{$\begin{array}{l}\text { Expected conc. (ng } \\
\mathrm{mL}^{-1} \text { ) }\end{array}$} & \multicolumn{3}{|l|}{ Intraday $(n=5)$} & \multicolumn{3}{|l|}{ Interday $(n=5)$} & \multicolumn{2}{|c|}{ Observed concentration $(n=5)$} \\
\hline & $\begin{array}{l}\text { Estimated conc. } \bar{x} \pm S D \\
\text { (ng mL-1) }\end{array}$ & $\begin{array}{l}\text { Precision } \\
\text { (RSD\%) }\end{array}$ & $\begin{array}{l}\text { Accuracy } \\
\text { (RE\%) }\end{array}$ & $\begin{array}{l}\text { Estimated conc. } \\
\bar{X} \pm S D\left(n g \mathrm{~mL}^{-1}\right)\end{array}$ & $\begin{array}{l}\text { Precision } \\
\text { (RSD\%) }\end{array}$ & $\begin{array}{l}\text { Accuracy } \\
\text { (RE\%) }\end{array}$ & $\begin{array}{l}\text { Values of the } \\
\text { recovery (\%) }\end{array}$ & $\begin{array}{l}\text { Mean recovery } \\
\% \pm S D\end{array}$ \\
\hline 20 & $22.43 \pm 1.54$ & 8.13 & 7.14 & $21.05 \pm 0.97$ & 4.21 & 5.25 & $87.57-108.73$ & $98.15 \pm 9.52$ \\
\hline 100 & $106.47 \pm 2.43$ & 2.34 & 6.47 & $104.98 \pm 6.05$ & 5.90 & 4.98 & $92.08-103.61$ & $97.85 \pm 5.83$ \\
\hline 500 & $479.89 \pm 15.80$ & 3.31 & -4.02 & $486.07 \pm 22.46$ & 4.58 & -2.79 & $98.59-111.65$ & $105.12 \pm 7.00$ \\
\hline
\end{tabular}

“Concentrations" are abbreviated as “conc.", SDF: Sildenafil, SD: Standard deviation, RSD: Relative standard deviation, RE: Relative error 
Table 4. Results of SDF values determined in HDSs

Sample number

The presentation The detected

of the product SDF amount

Sample

The presentation The detected Sample

The presentation The detected (mg/g)

number

of the product

SDF amount number

of the product

SDF amount

(mg/g)

(mg/g)

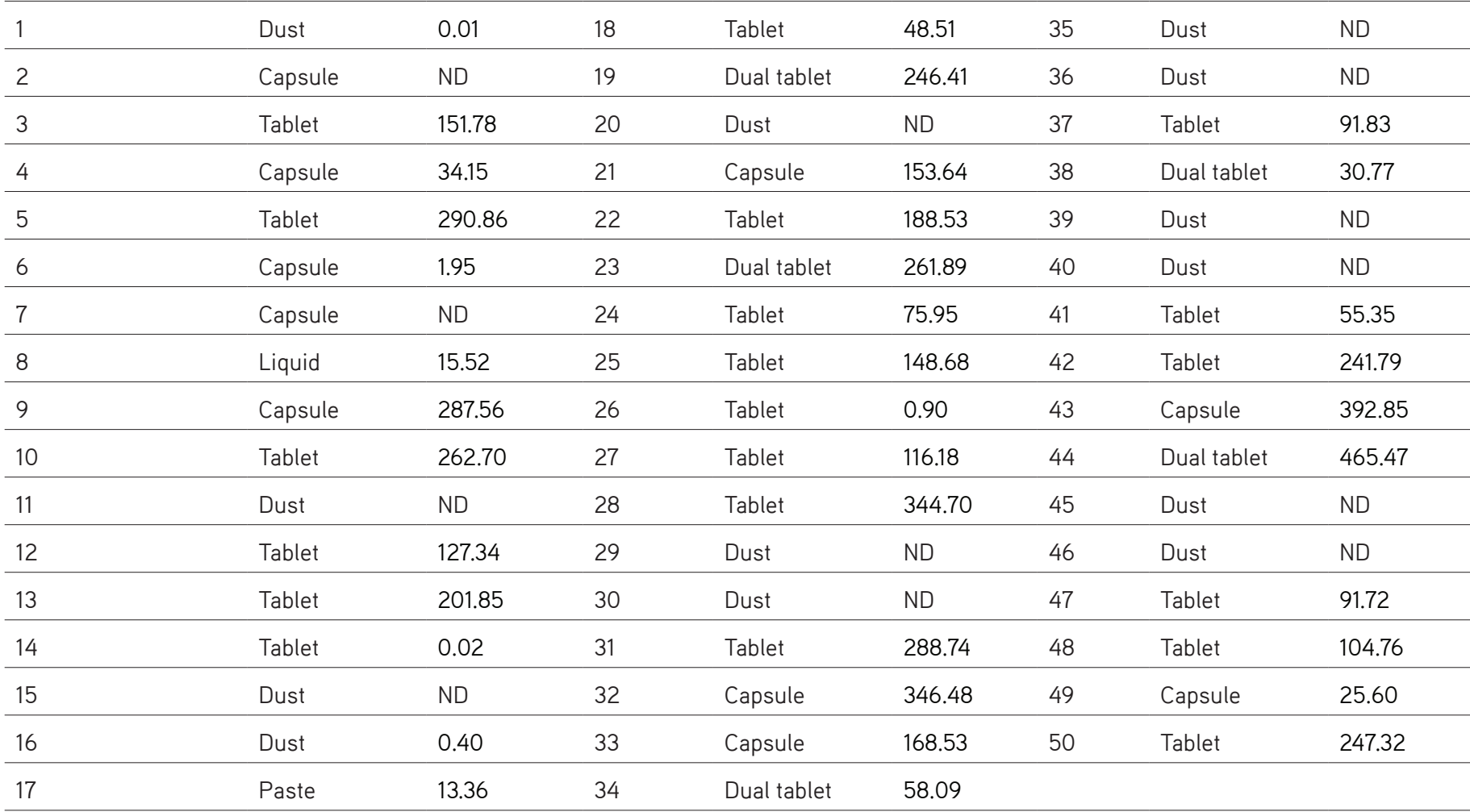

Minimum detected concentration

0.01

Maximum detected concentration

465.47

Average

150.87

Standard deviation

127.48

SDF: Sildenafil, HDSs: Herbal dietary supplements, ND= Not detected

Table 5. The validation parameters and chromatographic properties of SDF determination methods in the literature

\begin{tabular}{|c|c|c|c|c|c|c|c|c|}
\hline Study & LOQ & $\begin{array}{l}\text { Retention } \\
\text { times (min) }\end{array}$ & Linearity & Linear range & Mobile phase & $\begin{array}{l}\text { Flow } \\
\left(\mathrm{mL} \min ^{-1}\right)\end{array}$ & $\begin{array}{l}\text { Detector and } \\
\text { detection value }\end{array}$ & $\begin{array}{l}\text { Total analysis } \\
\text { time (min) }\end{array}$ \\
\hline $\begin{array}{l}\text { Reddy and } \\
\text { Reddy } \\
2008^{7}\end{array}$ & $8.2 \mathrm{ng} \mathrm{mL}^{-1}$ & 4.1 & 0.9990 & $0.1-30 \mu \mathrm{g} \mathrm{mL}^{-1}$ & $\begin{array}{l}\text { Phosphate buffer }(\mathrm{pH} 7.0) \\
\text { and acetonitrile/ } \\
(3: 7, \mathrm{v} / \mathrm{v})\end{array}$ & 0.8 & $\begin{array}{l}\text { UV } \\
228\end{array}$ & 15 \\
\hline $\begin{array}{l}\text { Daraghmeh } \\
\text { et al. } .^{15} 2001\end{array}$ & $12.2 \mu \mathrm{g} \mathrm{mL}^{-1}$ & 9.5 & 0.9999 & $\begin{array}{l}2-12 \mu g \mathrm{~mL}^{-1} \\
64-257 \mu \mathrm{gL} \mathrm{mL}^{-1}\end{array}$ & $\begin{array}{l}0.2 \mathrm{M} \text { ammonium acetate } \\
(\mathrm{pH} 7.0) \text { and acetonitrile } \\
(1: 1, \mathrm{v} / \mathrm{v})\end{array}$ & 1 & $\begin{array}{l}\text { UV } \\
240\end{array}$ & 10 \\
\hline $\begin{array}{l}\text { Dinesh et } \\
\text { al. }^{16} 2002\end{array}$ & $0.05 \mu \mathrm{g} \mathrm{mL}^{-1}$ & 10.0 & 0.9995 & $0.05-7.5 \mu \mathrm{g} \mathrm{mL}^{-1}$ & $\begin{array}{l}\text { Water and acetonitrile } \\
(48: 52, \mathrm{v} / \mathrm{v})\end{array}$ & 1 & $\begin{array}{l}\text { UV } \\
245\end{array}$ & 10 \\
\hline $\begin{array}{l}\text { Nagaraju et } \\
\text { al. }{ }^{7} 2003\end{array}$ & - & 5.2 & 0.9950 & $90.5-99.9 \mu \mathrm{g} \mathrm{mL}^{-1}$ & $\begin{array}{l}0.05 \mathrm{M} \text { potassium } \\
\text { dihydrogen } \\
\text { orthophosphate and } \\
\text { acetonitrile }(3: 7 \mathrm{v} / \mathrm{v})\end{array}$ & 1 & $\begin{array}{l}\text { DAD } \\
230\end{array}$ & 15 \\
\hline
\end{tabular}

SDF: Sildenafil, LOQ: Limit of quantification, UV: Ultraviolet, DAD: Diode array detection 
products have been found to contain SDF in amounts that could threaten human health even after a single use.

In the present study, the established HPLC-UV method is fast, cheap, and accurate for reference laboratories concerned with food control or toxicology. The applicability of the developed method to herbal products was proved by analysis of 50 HDSs. At the same time, it was shown that herbal products marketed for the treatment of erectile dysfunction in the market contain high amounts of SDF, which can pose a risk to human health.

\section{ACKNOWLEDGEMENTS}

This research was supported by Scientific Research Projects Support Program of Sivas Cumhuriyet University (CÜBAP) under project number ECZ016.

Conflict of Interest: No conflict of interest was declared by the authors.

\section{References}

1. Ahn CY, Bae SK, Bae SH, Kang HE Kim SH, Lee MG, Shin WG. Pharmacokinetics of sildenafil and its metabolite, $\mathrm{N}$-desmethylsildenafil, in rats with liver cirrhosis and diabetes mellitus, alone and in combination. Xenobiotica. 2011;41:164-174.

2. Alitokka G, Atkosar Z, Sener E, Tunçel M. FIA of sildenafil citrate using UV-detection. J Pharm Biomed Anal. 2001;25:339-342.

3. Langtry HD, Markham A. Sildenafil: a review of its use in erectile dysfunction. Drugs. 1999;57:967-989.

4. Berzas Nevado JJ, Flores JR, Peñalvo GC, Rodríguez FN. Determination of sildenafil citrate and its main metabolite by sample stacking with polarity switching using micellar electrokinetic chromatography. J Chromatogr A. 2002;953:279-286.

5. Cooper JD, Muirhead DC, Taylor JE, Baker PR. Development of an assay for the simultaneous determination of sildenafil (viagra) and its metabolite (UK-103,320) using automated sequential trace enrichment of dialysates and high-performance liquid chromatography. J Chromatogr B Biomed Sci Appl. 1997;701:87-95.

6. Barnett CF, Machado RF. Sildenafil in the treatment of pulmonary hypertension. Vasc Health Risk Manag. 2006;2:411-422.

7. Reddy BP, Reddy KA, Reddy MS. Validation and stability indicating RPHPLC method for the determination of tadalafil API in pharmaceutical formulations. Res Pharm Biotechnol. 2010;2:1-6.

8. Al-Ghazawi M, Tutunji M, AbuRuz S. Simultaneous determination of sildenafil and $\mathrm{N}$-desmethyl sildenafil in human plasma by highperformance liquid chromatography method using electrochemical detection with application to a pharmacokinetic study. J Pharm Biomed Anal. 2007;43:613-618.

9. Karatza AA, Bush A, Magee AG. Safety and efficacy of Sildenafil therapy in children with pulmonary hypertension. Int J Cardiol. 2005;100:267-273.

10. Lewis RJ, Johnson RD, Blank CL. Quantitative determination of sildenafil (Viagra) and its metabolite (UK-103,320) in fluid and tissue specimens obtained from six aviation fatalities. J Anal Toxicol. 2006;30:14-20.
11. Abdel-Hamid Me. Determination of sildenafil, tadalafil, and vardenafil in tablets and adulterated herbal products by ESI-MS-MS. J Liq Chromatogr Relat Technol. 2006;29:591-603.

12. Mikami E, Ohno T, Matsumoto H. Simultaneous identification/ determination system for phentolamine and sildenafil as adulterants in soft drinks advertising roborant nutrition. Forensic Sci Int 2002;130:140146.

13. Harikrishna K, Nagaralli BS, Seetharamappa J. Extractive Spectrophotometric Determination of Sildenafil Citrate ( Viagra ) in Pure and Pharmaceutical Formulations. 2008;16:11-17.

14. Chien C, Wang C, Fernandez LP. Spectrofluorimetric Determination of Sildenafil : A New Analytical Alternative for Its Analysis. J Chinese Med Res Dev. 2012;1:54-60.

15. Daraghmeh N, Al-Omari M, Badwan AA, Jaber AM. Determinaton of sildenafil citrate and related substances in the commercial products and tablet dosage form using HPLC. J Pharm Biomed Anal. 2001;25:483492.

16. Dinesh ND, Vishukumar BK, Nagaraja P, Made Gowda NM, Rangappa KS. Stability indicating RP-LC determination of sildenafil citrate (Viagra) in pure form and in pharmaceutical samples. J Pharm Biomed Anal. 2002;29:743-748.

17. Nagaraju V, Sreenath D, Rao JT, Rao RN. Separation and determination of synthetic impurities of sildenafil (Viagra) by reversed-phase highperformance liquid chromatography. Anal Sci. 2003;19:1007-1011.

18. Yang YJ, Song DM, Jiang WM, Xiang BR. Rapid resolution RP-HPLC-DAD method for simultaneous determination of sildenafil, vardenafil, and tadalafil in pharmaceutical preparations and counterfeit drugs. Anal Lett. 2010;43:373-380.

19. Zhu X, Xiao S, Chen B, Zhang F, Yao S, Wan Z, Yang D, Han H. Simultaneous determination of sildenafil, vardenafil and tadalafil as forbidden components in natural dietary supplements for male sexual potency by high-performance liquid chromatography-electrospray ionization mass spectrometry. J Chromatogr A. 2005;1066:89-95.

20. Man CN, Nor NM, Lajis R, Harn GL. Identification of sildenafil, tadalafil and vardenafil by gas chromatography-mass spectrometry on short capillary column. J Chromatogr A. 2009;1216:8426-8430.

21. Popescu AM, Radu GL, Onisei T, Raducanu AE, Niculae CG. Detection by gas chromatography-mass spectrometry of adulterated food supplements. Rom Biotechnol Lett. 2014;19:9485-9492.

22. Tseng MC, Lin JH. Determination of sildenafil citrate adulterated in a dietary supplement capsule by LC/MS/MS. J Food Drug Anal. 2002;10:112-119.

23. Liang $Q, Q u J$, Luo G, Wang Y. Rapid and reliable determination of illegal adulterant in herbal medicines and dietary supplements by LC/MS/MS. J Pharm Biomed Anal. 2006;40:305-311.

24. ICH. International Conference on Harmonization (ICH) of Technical Requirements for the Registration of Pharmaceuticals for Human Use, Validation of Analytical Procedures: Methodology (ICB-Q2B) (1996). http://www.ich.org/fileadmin/Public_Web_Site/ICH_Products/ Guidelines/Quality/Q2_R1/Step4/Q2_R1__Guideline.pdf 